Article

\title{
Towards a Conceptualization of Young People's Political Engagement: A Qualitative Focus Group Study
}

\author{
Ana Pontes ${ }^{1, *}$, Matt Henn 1 (D) and Mark D. Griffiths ${ }^{2}$ (D) \\ 1 Department of Politics and International Relations, Nottingham Trent University, \\ Nottingham NG1 4FQ, UK; matt.henn@ntu.ac.uk \\ 2 Department of Psychology, Nottingham Trent University, Nottingham NG1 4FQ, UK; \\ mark.griffiths@ntu.ac.uk \\ * Correspondence: anaisabelpontes@gmail.com; Tel.: +44-115-848-8156
}

Received: 13 November 2017; Accepted: 5 March 2018; Published: 8 March 2018

\begin{abstract}
Disenchantment with politics and low electoral turnout does not mean young people are not engaged with politics. However, our understanding of what being 'politically engaged' entails is somewhat challenged by the lack of consensus concerning the definition of this particular concept. Furthermore, existing conceptualizations of political engagement and participation (offline and online) often center on a limited set of political action items, failing to realize that a person can be politically engaged but not participate in political actions. Despite attempts to understand how young people themselves define politics, there are insufficient youth specific explanations of what being politically engaged means. In the present study, focus groups including young people (18-24 years) were conducted to examine understandings of political engagement. Participants were also asked to group a set of items they considered most accurately assessed this construct. Using the results, a conceptualization is proposed taking into account young people's definitions of political engagement; this suggests that young people consider political engagement to have emotional and cognitive dimensions but also to be conceptually distinct from political participation.
\end{abstract}

Keywords: political engagement; political participation; young people; focus groups

\section{Introduction}

Political participation and political engagement are considered to be necessary conditions for democracy to function effectively [1]. However, research into political engagement has received increased attention across established democracies, not least because of what is considered to be an ongoing disconnect between citizens and their states (e.g., [2-6]). Young people are frequently singled out as a problematic group, displaying low levels of electoral turnout, a lack of trust in democratic institutions and signs of skepticism and cynicism regarding politicians and political parties [7]. While activities associated with traditional politics have declined, young people have also found interest in political issues [8] and alternative forms of political participation [9].

Nevertheless, the conventional image that prevails is that young people are politically 'disinterested' or even 'apathetic' when compared with older generations [10]. In her paper about differences in political participation between young and old people, Quintelier [11] identified three reasons for these characterizations of youth and the perceived political participation gap between younger and older people. Firstly, due to life cycle and generational effects; secondly, the attractiveness of new forms of participation has caused younger people to divert from traditional forms of political participation as practiced by older generations (such as voting); and thirdly, that there is a difference in 
the way young people embrace politically related conceptions compared to older people. Of these, the third reason is the most relevant for the context of this paper given that it is important to highlight that avoiding such definitional discrepancies is critical in social research. It is not sufficient in itself for a researcher to offer a definition of the investigated topic but also for that definition to be used and accepted by the surveyed population. Researchers should be careful that the acts that they consider to represent political engagement are likewise considered as political engagement acts by a younger audience. For example, Parry and colleagues [12] identified a huge discrepancy between the definitions of politics espoused by older and younger people, a finding that has also been suggested in other studies (e.g., [13,14]).

Some researchers have already identified how young people think about and engage in politics-leading to the emergence of significant paradigm controversies concerning differences between political 'participation' and 'engagement' (e.g., [15-18]). Following debates on young people's apparent lack of political engagement, there has been discussion concerning the validity and reliability of the instruments used in such research. For instance, one position claims existing measures used to assess young people's engagement need refinement in order to capture the full range of behaviors that being engaged entails (e.g., [2,6,8]). According to Albacete [2], properly validated measures of youth political engagement are lacking. Consequently, wider research assessing the youth political engagement construct may be susceptible to usage of inconsistent criteria that lack statistical/psychometric validity. Such practices may result in biased statistical conclusions, since the main outcome would be assessed improperly. Furthermore, answering questions concerning young citizens' political engagement requires coherence between the concept which implies a broader repertoire of actions (than the existing standardized measures) that citizens can get involved in-and its assessment. To address this, it is essential to develop an instrument to adequately assess the political engagement construct among contemporary youth [19].

However, before developing such a scale, there are specific aspects that should be taken into account to adequately assess political engagement among young people. Firstly, the instrument should allow the assessment of the latent concept of political engagement, the broad number of forms it can take, the different levels of intensity and difficulty those activities entail, and its dimensionality. It should also take into account recent developments in the youth repertoire of political actions. Finally, it should allow the equivalent assessment of political engagement in several countries and over time [2]. Given that evidence from the UK and Western Europe suggests that young people are not politically apathetic but have their own views about political issues and engage in democratic politics through a variety of modes of participation [20-22], their understandings have to be explored in order to better understand the ways in which they engage in politics. Moreover, White and colleagues [23] also argue that "without clear understanding of how young people conceptualize political interest and engagement, it is difficult to know how they interpret such questions or the reasons for their responses" (p. 1). The authors note that many young people are engaged in activities which may illustrate political engagement to the researcher but which young people themselves do not consider to be representing that construct - thus incurring a problem of under-reporting of political engagement among young people.

The purposes of this paper are twofold. Firstly, to propose a specific definition of young people's political engagement—since before developing measures to evaluate such a concept, there is a need to clarify its definition [24]. Also, the present paper aims to understand whether (and if so, how) the definitions of political engagement and political participation emerging from this study of young people differ from those found elsewhere in the literature. Previous studies have investigated what political participation means to Spanish students [25], understandings of citizenship among Turkish and Roma youth [26], young people's perspectives on what politics means to them [27] and which behaviors Swedish young people associate with political engagement [17]. However, there are no studies conducted in Britain or Portugal that specifically consider young people's conceptual definitions of political engagement. 
The second aim is to provide qualitative insights into how young people perceive political engagement. What does being 'engaged' in politics mean to them? Would they consider engagement and participation in politics to be the same, or are they perceived differently? First, this paper provides an overview of the existing conceptualizations of political engagement and political participation and the distinctions between these two concepts. Second, the results from a series of four focus groups with young people aged 18-24 years are presented and the findings offer an original contribution to advance the assessment of young people's political engagement.

\section{Conceptual Definitions of Political Engagement and Political Participation}

Any advance in understanding young people's political engagement requires clarity on what conceptual approach to use. However, the literature displays a lack of agreement on how best to define political engagement and how to distinguish it from related concepts such as political participation [16]. For instance, while these concepts relate to different phenomena, the distinctiveness of each is left wanting $[1,28]$. In order to gain a clear understanding of the key features of-and how to assess-young people's political engagement, it is important to critically examine the differences between political engagement and political participation.

\subsection{Political Participation}

When Verba, Nie and Kim [29] defined political participation in The Civic Culture, they referred to "legal acts by private citizens that are more or less directly aimed at influencing the selection of governmental personnel and/or the actions that they take" (p. 1). A similar characterization is offered by Parry, Moyser and Day [12] in their British study, while Brady [30] claimed political participation should first-and-foremost be considered as manifested and observable actions or activities in which people voluntarily participate. These definitions all relate to actions taken by citizens for purposes of influencing governments. They are reflected in more recent conceptualizations $[1,31]$ as the "involvement of citizens (in the broader sense including public subjects like organizations, groups, etc.) in political processes, decision making ceremonies, as well as citizens influence on the formation of political systems and institutions, their operation, drafting political decision" ([31], p. 206).

Additionally, alternative typologies of political participation have been developed. Verba and Nie [32] listed four types of participation, including voting, participating in campaign activity, contacting public officials and participating in cooperative or communal activities. Using Verba and Nie's work, Teorell, Torcal and Montero [33] proposed a similar yet broader typology encompassing five activities (electoral participation, consumer participation, party-based activity, protest activity and contact activity). Such typologies are not without critics. Ekman and Amnå [16] contend they are somewhat limited in that they fail to consider latent-or 'pre-political'-political participation forms such as being a member of charity organizations, or watching the news on television. They claim pre-political behavior is crucial for understanding new forms of political behavior and of the prospects for future political participation. Barrett and Zani [1] argue political participation can take many different forms. In addition to conventional methods such as voting, non-conventional forms may involve signing petitions, participating in political demonstrations, writing political blogs and daubing political graffiti on buildings $[2,16,34]$.

Recent political participation typologies tend to be broader in scope and definition. As young people are increasingly abstaining from traditional forms of politics (e.g., electoral participation), a gradual transformation of political participation modes appears to be taking place [35] and authors distinguish between conventional/formal/traditional forms of political participation and non-conventional/informal/alternative forms, as well as between latent and manifest forms of political participation (e.g., $[15,36])$. Rather than indicating a steady withdrawal from political life, these new participation modes reflect a new type of critical citizen [37] who still supports basic democratic values but is skeptical of conventional systems of representation and mediation and prefers participation in more horizontal and autonomous ways [38,39]. 


\subsection{Political Engagement}

Although often synonymous with political participation, political engagement can be distinguished from that concept in a number of ways. Carreras [40] differentiates between cognitive and active political engagement. Here, cognitive political engagement refers to a citizen's psychological attachment to the political system, including whether they are politically interested, seek political information, and identify with a particular political party. On the other hand, active political engagement manifests itself in a higher probability of contacting politicians, attending political party meetings, and participating in town public meetings. In their study of adolescents' political engagement attitudes, Eckstein, Noack and Gniewosz [41] emphasized an attitudinal dimension including responses to items such as 'somebody who complains about political parties should join a party to change it' and 'we should participate more in politics to influence political decisions' (p. 494).

Recently, McCartney and colleagues [42] have conceptualized political engagement as a specific type of civic engagement, which they postulate as a means of participating in and seeking to influence the life of, a community. Political engagement refers more explicitly to politically-oriented activities that seek a direct impact on political issues, systems and structures. As an example, they contrast "participating in a community recycling program" with "working to enact community laws regarding recycling" ([42], p. 14). Both demonstrate civic engagement but only the latter indicates political engagement. Another definition of political engagement was presented in the "European Processes Influencing Democratic Ownership and Participation" (PIDOP) project. Here, Barrett [43] contended that engagement could be considered as a precondition to participation and suggested that a state of engagement encompasses behaviors but also includes a psychological dimension where individuals' cognitions and emotions are also taken into account. Thus, assuming that political engagement involves participatory behaviors which are directed towards the polity, someone may also have interest in, pay attention to and have knowledge, opinions or feelings concerning political matters without necessarily participating in any overt actions towards the polity. In other words, individuals may be cognitively or emotionally engaged without necessarily being behaviorally engaged. For example, cognitive engagement can be demonstrated via levels of political or civic knowledge, or levels of attention to media sources such as newspapers, news on the Internet and the extent to which an individual discusses politics or civic affairs with family or friends; emotional engagement may be demonstrated by the intensity of feelings about political or civic matters.

Following Barrett's [43] conceptualization of political engagement, Emler [44] proposed that political engagement should be regarded as a developmental process, the central element of which is some driver to pay attention to politics. In a discussion concerning the essence of being a political actor in a multicultural society, Emler offered the view that the two prime candidates for the motivational role of being politically engaged are interest in politics and a sense of civic duty and that these can work either in combination or as alternatives. Attentiveness to what is happening in the political arena or active information searching (as indicated by such activities as reading articles about politics in newspapers, reading literature produced by political parties, listening to broadcasts specifically about politics and discussing politics with others), in its turn underpins the extent to which individuals may become politically informed. Political information-how much people know about politics-then provides the basis on which opinions are formed or judgements are made. Opinions in their turn may then become organized into more integrated, overarching structures. The author proposes that such structures are in effect the bases for the more stable political identities and therefore for someone to become a political actor.

Discussions of political participation and political engagement also take place in online environments. Different terms are used such as 'e-participation' [45] or 'digitally networked' participation [46] -although most authors simply characterize these as online participation and engagement (e.g., [47-49]). Typically, online definitions are adapted from offline definitions (e.g., [50]), including searching for online political information, contacting politicians via the Internet [51], or petitioning online [52]. However, some regard such online activity as lacking political substance 
and for instance, the term 'slacktivism' has been coined when referring to political participation and engagement online. Christensen [53] succinctly defined slacktivism as the "political activities that have no impact on real-life political outcomes but only serve to increase the feel-good factor of the participants" (p. 1). Furthermore, slacktivism has also been used to denote politically ineffective online actions, therefore having a negative connotation [54].

\section{Towards a Conceptualization of Youth Political Engagement}

This paper has identified and critically examined existing conceptualizations of (offline and online) political dis/engagement and political non/participation and examined the extent to which they overlap and differ. This serves as context for the construction of a scientific definition of young people's political engagement which we aim to achieve through the remainder of this paper. Since the target population is youth and the political engagement conceptualizations identified in this critical examination of the literature were drawn predominantly for the general adult population, there is a need to develop a conceptual definition of political engagement that takes into account young people's perceptions of political engagement. Moreover, a 'bottom-up' youth-led approach was chosen, because it involves young people defining their own approach to political engagement and gives them some freedom regarding the ways in which they view this particular phenomenon [55]. Nevertheless, Coles also suggests that research should be conducted that takes into account young people's views if the aim is a deeper involvement of young people with politics [56].

Following the point made in the Introduction and considering that young people and adults perceive reality differently [57] and have different conceptions of what politics means [12], it is important to systematically identify and understand the implications that a conceptual misunderstanding might have for future research; of equal importance is to reach conclusions that are as representative as possible of young people's patterns of political engagement. The purpose is to gain a deeper, more nuanced and valid understanding of young people's political engagement than currently exists - one which fully articulates the breadth and different dimensions of their political engagement in the context of their current disillusionment with democratic politics $[14,39,58]$.

\section{Research Design}

In this study, we explore youth perspectives on what it means to be politically engaged via three key research questions:

- What are young people's general perceptions of political engagement and how do these contrast with their characterization of political participation, both in theory and in practice?

- Are young people's definitions of political engagement different from existing definitions of this concept?

- What behaviors and actions do young people regard as political engagement indicators?

The present sample includes young people living in Britain and Portugal. These countries were selected for study because they represent two European democracies with similar and very low recent levels of election turnout (Portugal, 55.8\% in 2015; United Kingdom (UK), 68.7\% in 2017 [59]) and both display similar patterns of contemporary youth political engagement [60] ${ }^{1}$. Moreover, in a study on political participation of young people in the European Union, Sloam [63] concluded that Portugal and Britain were also two of the countries where young people's turnout to vote is below the EU15 average and have also very low levels of participation in politics in general. Using data from the European

1 There is no recent evidence of specific youth election turnout published in Portugal due to the data privacy legislation in that country [61]. However, survey data from 2013 suggests that both Portugal and the UK have some of the lowest youth election turnout rates when asked, "During the last 3 years, did you vote in any political election at the local, regional or national level? If you were, at that time, not eligible to vote, please say so" [62]. 
Social Survey (ESS) from 2000 to 2002, Albacete [2], found that the average levels of young people's institutional political participation is the same for both Portugal and Britain. Similarly, Fieldhouse, Tranmer and Russell [64] reported that the ESS estimate percentages for the general election's turnout of both Portugal and the UK was respectively 75.9 and 73.2 (using data from 2002 to 2003) for the overall population. Regarding young people between 18 and 24 years old, Fieldhouse and colleagues estimated that the percentages were 47 for Portugal and 31.6 for the UK [64]. Moreover, it has been reported that the patterns of engagement with and participation in politics are relatively similar across West-European countries (e.g., [65]). Despite these similarities, some evident differences have been noted regarding young people's political engagement in both Portugal and Britain [60]. The present analyses permit a nuanced understanding of whether there are particular differences in terms of how young people from broadly similar European countries perceive political engagement, or whether their understandings are similar. Moreover, it is important to highlight that although two different countries were used in this research, there was no underlying intention to offer a comparison between each. Instead, the rationale for conducting the research in these different countries was to demonstrate that the data had value beyond one country case rather than being unique and particular to one specific cultural context.

This is an exploratory rather than a hypothesis-driven study. Focus-group methodology was chosen to investigate meanings, ideas, beliefs, and values, allowing deeper examination of youth perceptions concerning political engagement (e.g., [66]). The groups were conducted both offline in-person (Britain) and online (Portugal).

\subsection{Participant Recruitment}

Eighteen young people aged between 18 and 24 years participated in the study. Four focus groups of mixed gender were conducted during October and November 2016, two with British-based young people $(\mathrm{N}=8)$ while the other two included Portuguese youth $(\mathrm{N}=10)^{2}$. The sizes of the focus groups ranged from three to five participants.

The research participants were recruited using a two-step process. For the British and Portuguese focus groups, an email explaining the aims and purpose of the research was sent to university colleagues and each were asked to help find people who met the sampling requirements (of being British or Portuguese aged 18 to 24 years and that both genders should be evenly distributed across the groups). Willing participants were then screened for eligibility and were asked to identify participants to take part in the research. Requests for volunteers were also posted on social media (i.e., Facebook and Twitter). This snowball sampling strategy [68], is commonly used across qualitative studies in the field of political engagement and political participation (e.g., [69]) and in particular allows researchers to increase the diversity of the participants [68]. This approach uses a set of initial participants who nominate other participants who are eligible to participate from their social networks [70]. Furthermore, although age and an equal gender distribution were taken as characteristics that the sample should meet, no other characteristics were required. Due to the exploratory nature of this paper, other characteristics were not taken into account, since the objective was not to compare the different participants' answers according to their characteristics but to understand if a pattern concerning their understanding of political engagement could be identified across youth.

2 For this study the authors were satisfied with 18 participants, given that after every focus group, the definitions of political engagement given by young people were analyzed and reached the point where the second focus group conducted for each country did not add much beyond the findings from the first focus group for each country (that is, that theoretical and data saturation had been achieved). Moreover, as Carlsen and Glenton [67] have noted, focus groups should be the unit of analysis in focus group studies, meaning that the sample size should refer to number of groups and not to the total number of participants in a study. Additionally, it has been recommended that focus groups should range from two to five groups per category of participants [67]. Since participants belonged to two different nationality categories (British and Portuguese) and two focus groups for each of these categories was conducted, the present study met the methodological requirements previously specified by Carlsen and Glenton. 


\subsection{Materials and Procedure}

Of the four focus groups conducted, two (British) were carried out in person and the remaining two (Portuguese) were carried out online. All the four group interviews lasted approximately one hour and were each facilitated by the first author. The offline focus groups were conducted on university campus, given that all the participants were students from the same university. With the participants' permission, the group interviews were audio recorded and the researcher-moderator also recorded notes to capture key themes and additional data such as body language and other aspects of the discussions that would otherwise remain lost if relying solely on audio equipment. Group interviews conducted online were synchronous and were conducted using the chat tool available on Facebook. Due to the popularity, affordability, and ease of access of this particular online social platform, researchers are increasingly utilizing this approach to conduct studies in a variety of different areas of study (e.g., [71-75]). However, given the different nature of the focus groups conducted (i.e., offline and online), a few considerations were taken into account before implementing them. A study conducted by Brüggen and Willens [76] concluded that it was methodologically feasible to use these different approaches within the same study and to do so with confidence. The authors critically compared online focus groups and offline focus groups with respect to their depth, breadth, efficiency, group dynamics, non-verbal impressions and respondent attitudes. Their findings demonstrated a high degree of similarity between the online and offline focus groups in terms of each of the characteristics analyzed. The experience gained from conducting online and offline focus groups in our study-and further details on the differences and implications identified-are discussed later in this paper.

A single semi-structured discussion guide was developed to ensure consistency in the areas of discussion addressed for each focus-group. This guide enabled the exploration of participants' perceptions of political engagement as well as comparison of the responses between the groups. The questions were theoretically-based and guided by the discussion outlined above concerning conceptual comparisons of political engagement and political participation. Following procedures suggested by Krueger and Casey [77], each group discussion began with a general question that explored participants' views on the importance for discussing the topic of young people's political engagement. This was followed by items designed to address the three research questions, including their experiences of politics and what meanings they ascribed to politics. Following this, images shared on Twitter were presented to evoke Brexit (since it was a topical issue at the time that the focus groups were conducted) as well as notions of solidarity, which were designed to encourage participants to think about political engagement in its wider sense and to discuss how they conceptualized political engagement.

Each participant was then asked to write down three to five behaviors they perceived to be political engagement and these were then discussed in the group. This was a completely open exercise and no prompts were given to participants-they were allowed to offer any political engagement items that they considered important. Following this, each participant was presented with a list of 100 items that are commonly used within the literature to assess the politically related constructs of political engagement and political participation (such as political self-efficacy or civic engagement). They were asked to select a total of 20 items that they considered to represent the most complete set of activities and behaviors concerning young people's political engagement. Through this process, each participant developed a scale assessing the concept. Finally, the group collectively discussed their choices and each participant was then asked to share their thoughts and opinions on the value and appropriateness of the political engagement scales generated during the focus group.

\subsection{Data Analysis}

The British-based (in-person) focus groups were transcribed from audio, while the nature of the online focus groups with the Portuguese youth was such that the transcripts were automatically captured by the online social platform used for the discussions. All data in Portuguese were translated to English. Interview transcripts were analyzed using thematic analysis following the approach of 
Corbin and Strauss [78]. The coding process encompassed three stages that allowed for the uncovering of different dimensions of information and meaning at every stage of research.

The first step involved open-coding of the data to identify the properties and formation of a number of emergent concepts. Each concept or category were treated as a 'code' —an empirical element with a specific value. The second stage used was 'axial coding.' After identifying a number of codes, the associations between those codes were identified. The third step involved 'selective coding' that permitted confirmation of the existence of any emergent relationships from the first and second stages by examining the categories created and data that were included and omitted. This process of coding led to the formation of four key themes comprising: (i) the importance of the topic of young people's political engagement; (ii) attitudes and opinions toward voting (Brexit); (iii) political engagement-actions and behaviors; and (iv) defining political engagement.

Commonalities and differences amongst participants' views were noted concerning the role of politics in young people's lives, their general perceptions for engaging and participating in politics and their motivations. Furthermore, in order to ensure the quality of this analytical process, investigator and theoretical triangulation was taken into account [79]. Direct quotes were also used to provide illustrations of the concepts, as voiced through the experiences and attitudes of the focus group participants.

\section{Results}

Due to the aims of this paper (to propose a definition of young people's political engagement and to provide qualitative insights into how young people perceive political engagement), results are organized according to only two of the key themes identified: (i) political engagement-actions and behaviors, and (ii) defining political engagement. However, Table 1 includes all the four key themes and respective sub-themes that emerged from the data.

Table 1. Key themes and sub-themes that emerged from the focus groups analysis.

\begin{tabular}{cl}
\hline Key Themes & \multicolumn{1}{c}{ Sub-Themes } \\
\hline & $\begin{array}{l}\text { Politics is not a platform for young people to be involved; } \\
\text { Ambiguity on what political engagement means; } \\
\text { Difficult to find information about politics; } \\
\text { Ymportance of the topic of young } \\
\text { people's political engagement } \\
\text { Young people's political engagement happening online; } \\
\text { Poor citizenship education at schools; } \\
\text { Biased political news shared by the media; } \\
\text { Need to simplify/explain political jargon. }\end{array}$ \\
\hline $\begin{array}{c}\text { Voting: Attitudes and opinions } \\
\text { toward Brexit }\end{array}$ & $\begin{array}{l}\text { Impact of voting for Brexit; } \\
\text { Wearing a badge as a platform to induce political discussions; } \\
\text { Posting and sharing political information on social networking sites. }\end{array}$ \\
\hline Dofitical engagement actions \\
and behaviors
\end{tabular}$\quad$\begin{tabular}{l} 
Voting as a poor indicator of political engagement. \\
\hline
\end{tabular}

Theme 1. Political engagement-actions and behaviors.

Participants were asked to write three to five actions, behaviors, or ideas they consider as demonstrating political engagement and then to share responses with the others in the focus group, using their own words. Examples suggested by participants as illustrative of the concept resulted in two distinct categories, political engagement and political participation. Examples of political engagement included understanding politics and politicians, being involved in an organization, asking questions about world events, choosing sources of media they relied upon, showing interest in political news, sharing political opinions and attending political debates. In terms of political participation, 
actions included attending rallies, protesting (offline or online), fundraising and donating to parties, signing petitions, being an activist, voting and artistic performance. Initially, some participants raised voting as a political engagement item. However, after discussion, the general consensus was that voting was not as good a political engagement indicator as they had initially thought. They claimed it may be a purely expressive act without necessarily reflecting any knowledge about politics, or that voters had read party manifestos:

"A lot of people vote without knowing what they are doing, the impact it could have" P6 (British).

"A lot of young people that I know voted but they did not know why they were voting for, some of them voted because their parents told them to" P9 (Portuguese).

Participants' opinions diverged when asked whether or not the wearing of safety pins and the sharing of such actions via photos uploaded to social media (to express solidarity with non-UK citizens resident in Britain in the context of the vote for Brexit) indicated political engagement. Some participants stated that such young people could not be considered politically engaged because they were merely following trends and shadowing the actions of others without necessarily understanding the precise meaning of such actions. Other participants stated that such people could not be considered politically engaged because such actions simply reflected social influence-they observed other people posting a particular photo and wanted to do the same but that in doing so they were not expressing any intention to challenge or change xenophobic behaviors. Some participants disagreed, claiming that such actions signified an interest in and a following of, the news and current political events. Similarly, others considered such people to be politically engaged, since wearing a safety pin indicated awareness of what was happening in politics and of actively seeking to effect change, even if this involved a relatively small act. However, focus group participants also acknowledged that because such actions do not contribute to election outcomes, such displays are considered as of little consequence by those in power. Nonetheless, participants also recognized that with the rise of social media platforms, additional opportunities for political engagement are emerging and such 'symbolic' actions may represent a significant political action for those who perform them (such as sharing a video with political content or adding a frame to one's personal Facebook profile-image to signify support for a particular cause).

Following this, all participants were asked to choose 20 items from an offered list of 100 items. After collectively analyzing the items, participants then identified the most selected items (selected by at least three participants). Table 2 summarizes the 16 most selected items that were chosen by at least three participants in each of the four focus groups. These include understanding or holding political or civic values, discussing politics with family and friends, and paying attention to political events. On reflection while discussing these items, the key finding that emerged for these young citizens was that the concepts of political participation and political engagement entailed different actions and behaviors and were therefore considered by the participants to be different concepts. Furthermore, there were no evident differences between the items or activities selected by British and Portuguese young people. 
Table 2. Items selected by British and Portuguese young people.

\begin{tabular}{lcc}
\hline \multicolumn{1}{c}{ Selected Items } & BR (\%) & PT (\%) \\
\hline Looking for political information & $3(37.5)$ & $6(60)$ \\
Sending an email to a political organization & $3(37.5)$ & $3(30)$ \\
Voted & $5(62.5)$ & $8(80)$ \\
Discussed politics with friends / family & $4(50)$ & $7(70)$ \\
Engage in strike activity & $5(62.5)$ & $5(50)$ \\
Joined a political organization & $5(62.5)$ & $5(50)$ \\
Actively campaigned for a political organization & $3(37.5)$ & $5(50)$ \\
Paying attention to what is going on in politics & $3(37.5)$ & $5(50)$ \\
When having doubts about political issues, I ask questions and get involved in & $3(37.5)$ & $7(70)$ \\
debates about politics & $3(37.5)$ & $5(50)$ \\
I usually watch political debates (e.g., television, Facebook, YouTube) & $3(37.5)$ & $4(40)$ \\
Use the means you have as a citizen to critically monitor the actions of your & $4(50)$ & $6(60)$ \\
political representatives & $3(37.5)$ & $4(40)$ \\
Membership of a political party & $3(37.5)$ & $3(30)$ \\
Take part in protests, demonstrations, marches & $3(37.5)$ & $4(40)$ \\
Membership of a political lobbying and campaigning organizations & $3(37.5)$ & $8(80)$ \\
Signing petitions & \\
Understanding or holding political or civic values & \\
\hline
\end{tabular}

BR: Britain; BR (\%): Number or participants, from a total of 8 , who selected a certain item, with the respective percentage in parentheses; PT: Portugal; PT (\%): Number of participants, from a total of 10, who selected a certain item, with the respective percentage in parentheses.

\section{Theme 2. Defining political engagement}

When asked whether or not there is any distinction between political participation and political engagement, participants concluded that: (i) if individuals are politically participating they are normally considered as politically engaged but there were exceptions (such as voting without being engaged); and (ii) higher levels of enthusiasm and engagement lead to more participation. Other participants saw political participation as more conventional, electorally-oriented action as opposed to more passive and symbolic engagement methods (e.g., listening to the news). Analysis of all political engagement definitions offered by the young participants (using their own words, see Table 3), demonstrated the most recurrent ideas across political engagement definitions: (i) looking for information and being informed, (ii) being conscious, (iii) being involved, (iv) having an opinion, (v) being interested in political issues, (vi) being proactive and (vii) standing for one's beliefs:

"Because you can participate, by voting for example, without being engaged and then you vote without being informed ... because your parents told you to vote" P11 (Portuguese).

"If you are politically participating you are engaged but you can be engaged but not participate" P6 (British). 
Table 3. Young people's own definitions of political engagement. ${ }^{3}$

\begin{tabular}{|c|c|c|c|}
\hline Focus Group Iden & ation & Participant & Definition of Political Engagement \\
\hline \multirow{8}{*}{ British young people } & \multirow{5}{*}{ Focus group 1} & 1 & $\begin{array}{l}\text { Is choosing yourself to be politically active and not having your parents or anybody else influencing you and just actually making an effect and } \\
\text { doing your thing. }\end{array}$ \\
\hline & & 2 & $\begin{array}{l}\text { Do anything that you can do to make a change even if you feel alone or insecure, because you have the power to be informed } \\
\text { and engage yourself. }\end{array}$ \\
\hline & & 3 & $\begin{array}{l}\text { It is about looking for information and then deciding your opinion and sharing that with people and making discussions about political issues, } \\
\text { because we can talk about it, the thing is finding information and process that information and share it with our friends, colleagues. }\end{array}$ \\
\hline & & 4 & $\begin{array}{l}\text { It's finding out information for yourself and doing it because you want to and not because thought you have to } \ldots \text { discussing it and sharing it } \\
\text { and do your best to figure out things, gather all the information that you need for you to make decisions. }\end{array}$ \\
\hline & & 5 & $\begin{array}{l}\text { I think it is being pro-active, doing things your own, taking your own initiatives and going towards information, listening to debates, taking } \\
\text { your time and effort. }\end{array}$ \\
\hline & \multirow{3}{*}{ Focus group 2} & 6 & Taking an active interest in political matters and topics but not necessarily acting on this interest. \\
\hline & & 7 & Is when you show interest in any level of politics and political engagement has several levels in it and participation can be one of them. \\
\hline & & 8 & Engagement shows your interest in politics without official form of acts. It can be passive and more personal than participation. \\
\hline \multirow{10}{*}{ Portuguese young people } & \multirow{5}{*}{ Focus group 3} & 9 & $\begin{array}{l}\text { Is being interested in what's happening nowadays, being politically interested and that could be done in different ways but we should always } \\
\text { keep in mind that we should get out of our comfort zones. }\end{array}$ \\
\hline & & 10 & $\begin{array}{l}\text { It requires a compromise with what we stand for what we believe in. We don't need necessarily to participate but to be conscious of what is } \\
\text { happening in politics. }\end{array}$ \\
\hline & & 11 & Being politically engaged is being involved in politics and be clear about what we believe in and about our political opinions. \\
\hline & & 12 & $\begin{array}{l}\text { Involvement/interest/willingness to participate in constructive political debates, get out of your comfort zone and show your position about } \\
\text { political issues. }\end{array}$ \\
\hline & & 13 & $\begin{array}{l}\text { To be politically engaged we have to know the current political paradigm in which we find ourselves and be part of it through actions that } \\
\text { actually impact on it. }\end{array}$ \\
\hline & \multirow{5}{*}{ Focus group 4} & 14 & $\begin{array}{l}\text { Being politically engaged is expression your opinion about political questions, having interest and questions about politics and creating } \\
\text { debates about them. }\end{array}$ \\
\hline & & 15 & $\begin{array}{l}\text { All actions we do in our daily routine that affect politics could be considered as political engagement, from the small acts to the more relevant } \\
\text { ones, such as voting. }\end{array}$ \\
\hline & & 16 & Is being proactive in politics, conscious and informed about political issues ... We need to know how to intervene and how to have impact. \\
\hline & & 17 & $\begin{array}{l}\text { Is related to political, economic and social charisma with which a citizen can interact and learn from it. A politically engaged citizen should be } \\
\text { someone with knowledge, ideas and opinions could help improve or change the political reality. }\end{array}$ \\
\hline & & 18 & $\begin{array}{l}\text { Is related to the interest about political issues, standing for a position and a point of view and try to reach an agreement about diverse political } \\
\text { questions. Being politically engaged is being politically conscious. }\end{array}$ \\
\hline
\end{tabular}




\section{Discussion}

Our study provided insights into how young people themselves (in different national contexts, in Britain and Portugal) perceived political engagement, contributing towards a broader definition of young people's political engagement. There were no evident differences between young people from Britain and Portugal with respect to their perceptions of political engagement. The items selected and definitions created to illustrate political engagement were similar, regardless of participants country of origin. This poses the question whether this phenomenon of political engagement is generalizable or not across all national youth cohorts. For example, in a study of what political participation means to Spanish students, Sant [25] found that although young people were skeptical of the value of conventional electorally-oriented politics, they were able to articulate distinctions between such traditional forms of political participation and new alternative forms. In the present study, young people distinguished between what political participation is and what they understand it to be and how they contrast this with their understandings of political engagement.

All participants differentiated states of political engagement and political participation, which leads to the open debate about how to conceptualize political engagement and political participation (e.g., $[16,18,34,46])$. Is political engagement the same as political participation? In the present study, the eighteen participants across the four focus groups naturally differentiated between a state of engagement and participation and also suggested that political engagement seems to operate at a number of different levels. This reflects Emler's [44] notion that political engagement should be regarded as a developmental process, where the attention paid to politics seems to be the starting point. Furthermore, during the focus group discussions, the political engagement definitions offered by the young participants incorporated the ideas of being involved in and having knowledge of and opinions about politics. This confirms Barrett's [43] findings that political engagement comprises different psychological dimensions.

Across each of the four focus groups, participants acknowledged the value of Internet and social media platforms as options to engage politically, although they did not distinguish between the reality and veracity of online and offline actions such as sharing a video with political content on Facebook or signing petitions. In their opinion, each indicated political engagement. Although this finding fits with Christensen's definition of slacktivism (that online political activities have no impact on real-life political outcomes but instead serve only to increase the feel-good factor of the participants), it also challenges the negative connotation of slacktivism offered within some of the literature (e.g., $[53,54,80,81])$.

Previous studies have demonstrated young people associate politics with values and ideology, with political engagement perceived to be taking a position, having values and fighting for them [17]. However, when describing what they themselves understood political engagement to be, participants in our study evoked ideas such as looking for information and being informed, being conscious, being involved, having one's own opinions, showing interest in political issues, being proactive and standing-up for one's beliefs. Furthermore, participants did not refer to voting when discussing the main political engagement indicators-similar to other studies [17,82]. Recent evidence suggests that nowadays, young people prefer to engage with NGOs rather than with political parties because such organizations allow them to support particular issues they care about while not having to align to an entire package of political items [83]. This may explain why, in the present study, some of the items commonly chosen by young people as indicators of political engagement were linked to the community (e.g., promoting information and mobilization in the community to sustain political programs they believed in).

Regarding the different online and offline approaches taken in the present study, there are a number of implications that need to be highlighted. The use of both online and offline focus groups

3 The items are presented precisely as written by participants without any grammatical changes by the authors. 
enabled participants to provide deep reflections about the questions they were asked. The only aspect where the present study might have lost something by adopting these different approaches was that any non-verbal impressions were not observable in the online focus groups. However, this was counterbalanced by the fact that online communication is more anonymous, which may have facilitated respondents in being more honest in their views. The degree to which all aspects of the research questions were addressed in both online and offline focus groups was very good. Despite the different approaches, relevant data and similar findings were obtained in both settings. Concerning the group dynamics, it was interesting to note that participants from the online focus groups tended to interact more than was the case in the offline groups and they were particularly active in engaging in conversation and debate with others in their particular online group.

\section{Proposing a Definition of Young People's Political Engagement}

When analyzing young people's definitions of political engagement (Table 3) the most recurrent ideas were: looking for information and being informed, being conscious, being involved, having an opinion, being interested in political issues, being proactive, and standing for one's beliefs. The majority of these ideas were also identified by Barrett [43] in his definition of political engagement, that involved paying attention to and having knowledge, opinions or feelings concerning political matters. We therefore propose an update of Barrett's definition of political engagement to include some of the notions emerging from our focus groups with young people.

To map such a definition of political engagement that takes into account young people's realities and conceptions, we propose that political engagement should be defined as having interest in, paying attention to, having knowledge or opinions about, being conscious of, proactive about and constantly informed about politics. This engagement can happen both online and offline, since young people do not distinguish between these two realities. Furthermore, political engagement is understood as a psychological process that includes a cognitive and an emotional dimension. The cognitive dimension is defined as people's investment and willingness to exert the necessary efforts for the comprehension and mastering of complex ideas and of difficult skills related to political issues. Examples of cognitive political engagement actions might include searching for political information online, signing a petition online or offline, being interested in political agendas and watching political debates. The emotional dimension of political engagement reflects both the positive and negative reactions to politicians' actions and instructions, other people's opinions about politics, perceptions of party belonging, and beliefs about the value of politics. Examples of emotional political engagement may include posting/sharing one's own political thoughts or comments on social media for others to read, wearing or displaying a symbol or a sign representing support for a political cause, or holding and/or displaying feelings about political or civic matters.

This proposed definition was developed by taking into account the existing literature in the field of political engagement as well as the perceptions concerning political engagement held by young people generated through empirical observations through our focus group study. Further investigation is needed to explore whether or not this definition of political engagement may be extrapolated for young people in general.

\section{Conclusions}

Although our study is the first to qualitatively investigate young people's understandings of what it means to be specifically politically engaged (in both the British and the Portuguese context), it is not without limitations. Firstly, the exploratory nature of the research does not permit the drawing of any definitive conclusions. Secondly, all data were self-report and subject to well-known biases (recall bias, social desirability bias, etc.), and thirdly the participants were self-selected. However, the paper sought to develop a proposed definition of youth political engagement that is rooted in young people's own perceptions of what it means to be engaged. Such an approach ultimately enables those in the field to examine distinct conceptualizations systematically and consistently. 
In terms of the actions and behaviors chosen by young people to define political engagement (Table 2) and the definitions they offered (Table 3), a common pattern emerged independently of participant nationality. This pattern closely reflects the conceptions of political engagement followed in both Barrett and also Emler [15,44]. As a consequence, close attention has been given to their work throughout the present paper. Moreover, since the existing conceptualizations of different politically-related constructs (including political participation and political engagement) have usually been developed for entire all-age populations, this research contributes to the literature by considering the behaviors that specifically young people understand as illustrating political engagement. Young adult participants consider political engagement to be related to cognitive and emotional dimensions and the concept of political participation related with a behavioral (active) dimension. This strengthens the argument that when researching young people, political engagement and political participation should be considered as discrete concepts and therefore operationalized as independent concepts.

Acknowledgments: This work was supported by the Portuguese Foundation for Science and Technology (Fundação para a Ciência e Tecnologia [FCT]), grant number: SFRH/BD/131090/2017. The supporting agency had no role in the design or conduct of the study; collection, management, analysis, or interpretation of the data; preparation, review, or approval of the paper. The authors would also like to acknowledge comments by the anonymous reviewers which contributed to the improvement of this manuscript. Funding of this publication was provided by Nottingham Trent University.

Author Contributions: All three authors contributed to the design and conceptualization of the study. The first author carried out the focus group interviews, initially analyzed the data, and wrote the first draft of the paper. All authors contributed to interpretation of the data and to the many iterations of writing the paper following the first draft.

Conflicts of Interest: The authors declare no conflict of interest.

\section{References}

1. Barrett, M.; Zani, B. Political and Civic Engagement: Multidisciplinary Perspectives; Routledge: London, UK, 2014.

2. Albacete, G.G. Young People's Political Participation in Western Europe: Continuity or Generational Change? Palgrave Macmillan: New York, NY, USA, 2014.

3. Filetti, A. Participating unequally? Assessing the macro-micro relationship between income inequality and political engagement in Europe. Partecip. Confl. 2016, 9, 72-100.

4. Henn, M.; Oldfield, B. Cajoling or coercing: Would electoral engineering resolve the young citizen-state disconnect? J. Youth Stud. 2016, 19, 1259-1280. [CrossRef]

5. Kruikemeier, S.; Shehata, A. News media use and political engagement among adolescents: An analysis of virtuous circles using panel data. Political Commun. 2016, 34, 221-242. [CrossRef]

6. O'Toole, T. Beyond crisis narratives: Changing modes and repertoires of political participation among young people. In Politics, Citizenship and Rights; Kallio, K., Mills, S., Skelton, T., Eds.; Springer: Singapore, 2015.

7. Dalton, R.J. Citizenship norms and the expansion of political participation. Political Stud. 2008, 56, 76-98. [CrossRef]

8. Henn, M.; Foard, N. Young people, political participation and trust in Britain. Parliam. Aff. 2012, 65, 47-67. [CrossRef]

9. O'Toole, T. Engaging with young people's conceptions of the political. Child. Geogr. 2003, 1, 71-90. [CrossRef]

10. Dalton, R.J. Citizen Politics: Public Opinion and Political Parties in Advanced Industrial Democracies; CQ Press: Washington, DC, USA, 2013.

11. Quintelier, E. Differences in political participation between young and old people. Contemp. Politics 2007, 13, 165-180. [CrossRef]

12. Parry, G.; Moyser, G.; Day, N. Political Participation and Democracy in Britain; Cambridge University Press: Cambridge, UK, 1992.

13. Henn, M.; Weinstein, M.; Forrest, S. Uninterested youth? Young people's attitudes towards party politics in Britain. Political Stud. 2005, 53, 556-578. [CrossRef]

14. Hay, C. Why We Hate Politics; Polity: Camridge, UK, 2007. 
15. Barrett, M.; Brunton-Smith, I. Political and civic engagement and participation: Towards an integrative perspective. J. Civ. Soc. 2014, 10, 5-28. [CrossRef]

16. Ekman, J.; Amnå, E. Political participation and civic engagement: Towards a new typology. Hum. Aff. 2012, 22, 283-300. [CrossRef]

17. Sveningsson, M. 'I wouldn't have what it takes': Young Swedes' understandings of political participation. Young 2016, 24, 139-156. [CrossRef]

18. Van Deth, J.W. A conceptual map of political participation. Acta Politica 2014, 49, 349-367. [CrossRef]

19. Pontes, A.I.; Henn, M.; Griffiths, M.D. Assessing young people's political engagement: A critical and systematic literature review of the instruments used to measure political engagement. Int. Politics Rev. 2016, 4, 55-72. [CrossRef]

20. Kisby, B.; Sloam, J. Promoting youth participation in democracy: The role of higher education, in Beyond the Youth Citizenship Comission: Young People and Politics; Mycock, A., Tonge, J., Eds.; Political Studies Association: London, UK, 2014.

21. Briggs, J. Young People and Political Participation: Teen Players; Springer: London, UK, 2016.

22. Janmaat, J.G.; Keating, A. Are today's youth more tolerant? Trends in tolerance among young people in Britain. Ethnicities 2017. [CrossRef]

23. White, C.; Bruce, S.; Ritchie, J. Young People's Politics: Political Interest and Engagement Amongst 14-to 24-Year-Olds; Joseph Rowntree Foundation: York, UK, 2000.

24. Mueller, C.W. Conceptualization, Operationalization, and Measurement. In The Sage Encyclopedia of Social Science Research Methods; Lewis-Black, M.S., Bryman, A., Liao, T.F., Eds.; SAGE: Thousand Oaks, CA, USA, 2004.

25. Sant, E. What does political participation mean to Spanish students? JSSE J. Soc. Sci. Educ. 2015. [CrossRef]

26. Ataman, A.; Çok, F.; Şener, T. Understanding civic engagement among young Roma and young Turkish people in Turkey. Hum. Aff. 2012, 22, 419-433. [CrossRef]

27. Henn, M.; Weinstein, M.; Wring, D. A generation apart? Youth and political participation in Britain. Br. J. Politics Int. Relat. 2002, 4, 167-192. [CrossRef]

28. Adler, R.; Goggin, J. What do we mean by "civic engagement"? J. Trans. Educ. 2005, 3, 236-253. [CrossRef]

29. Verba, S.; Nie, N.H.; Kim, J.-O. Participation and Political Equality: A Seven-Nation Comparison; University of Chicago Press: Chicago, IL, USA, 1978.

30. Brady, H.E. Political participation. In Measures of Political Attitudes; Robinson, J., Shaver, P.R., Wrightsman, L.S., Eds.; Academic Press: San Diego, CA, USA, 1999.

31. Petrosyan, A. Methodological analysis of political participation indicator evaluation tools. Wisdom 2016. [CrossRef]

32. Verba, S.; Nie, N. Participation in America: Social Equality and Political Democracy; Harper \& Row: New York, NY, USA, 1972.

33. Teorell, J.; Torcal, M.; Montero, J.R. Political participation: Mapping the terrain. In Citizenship and Involvement in European Democracies: A Comparative Analysis; van Deth, J., Montero, J.R., Westholm, A., Eds.; Routledge: London, UK; New York, NY, USA, 2007.

34. Gibson, R.; Cantijoch, M. Conceptualizing and measuring participation in the age of the internet: Is online political engagement really different to offline? J. Politics 2013, 75, 701-716. [CrossRef]

35. Busse, B.; Hashem-Wangler, A.; Tholen, J. Two worlds of participation: Young people and politics in Germany. Sociol. Rev. 2015, 63, 118-140. [CrossRef]

36. Bimber, B.; Cunill, M.C.; Copeland, L.; Gibson, R. Digital media and political participation: The moderating role of political interest across acts and over time. Soc. Sci. Comput. Rev. 2015, 33, 21-42. [CrossRef]

37. Norris, P. Democratic Deficit: Critical Citizens Revisited; Cambridge University Press: Cambridge, UK, 2011.

38. Inglehart, R.; Welzel, C. Modernization, Cultural Change, and Democracy: The Human Development Sequence; Cambridge University Press: Cambridge, UK, 2015.

39. Tormey, S. The End of Representative Politics; Polity Press: Cambridge, UK, 2015.

40. Carreras, M. Compulsory voting and political engagement (beyond the ballot box): A multilevel analysis. Elect. Stud. 2016, 43, 158-168. [CrossRef]

41. Eckstein, K.; Noack, P.; Gniewosz, B. Attitudes toward political engagement and willingness to participate in politics: Trajectories throughout adolescence. J. Adolesc. 2012, 35, 485-495. [CrossRef] [PubMed] 
42. McCartney, A.R.M.; Bennion, E.A.; Simpson, D.W. Teaching Civic Engagement: From Student to Active Citizen; American Political Science Association: Washington, DC, USA, 2013.

43. Barrett, M. The PIDOP Project: An Overview. 2012. Available online: http:// epubs.surrey.ac.uk/775796/1/ Barrett\%20(2012).pdf (accessed on 7 March 2018).

44. Emler, N. What does it take to be a political actor in a multicultural society? In Nationalism, Ethnicity, Citizenship: Multidisciplinary Perspectives; Barrett, M., Flood, C., Eade, J., Eds.; Cambridge Scholars Publishing: Newcastle upon Tyne, UK, 2011.

45. Cantijoch, M.; Cutts, D.; Gibson, R. Moving slowly up the ladder of political engagement: A 'spill-over' model of internet participation. Br. J. Politics Int. Relat. 2016, 18, 26-48. [CrossRef]

46. Theocharis, Y. The conceptualization of digitally networked participation. Soc. Media Soc. 2015. [CrossRef]

47. Ekström, M.; Shehata, A. Social media, porous boundaries, and the development of online political engagement among young citizens. New Media Soc. 2016, 20, 740-759. [CrossRef]

48. Fu, K.-W.; Wong, P.W.C.; Law, Y.W.; Yip, P.S.F. Building a typology of young people's conventional and online political participation: A randomized mobile phone survey in Hong Kong, China. J. Inf. Technol. Politics 2016, 13, 126-141. [CrossRef]

49. Gil de Zúñiga, H.; Jung, N.; Valenzuela, S. Social media use for news and individuals' social capital, civic engagement and political participation. J. Comput. Mediat. Commun. 2012, 17, 319-336. [CrossRef]

50. Skoric, M.M.; Ying, D.; Ng, Y. Bowling online, not alone: Online social capital and political participation in Singapore. J. Comput. Mediat. Commun. 2009, 14, 414-433. [CrossRef]

51. di Gennaro, C.; Dutton, W. The internet and the public: Online and offline political participation in the United Kingdom. Parliam. Aff. 2006, 59, 299-313. [CrossRef]

52. Anduiza, E.; Gallego, A.; Cantijoch, M. Online political participation in Spain: The impact of traditional and internet resources. J. Inf. Technol. Politics 2010, 7, 356-368. [CrossRef]

53. Christensen, H.S. Political activities on the Internet: Slacktivism or political participation by other means? First Monday 2011, 16, 1-10. [CrossRef]

54. Morozov, E. The Net Delusion: The Dark Side of Internet Freedom; Public Affairs: New York, NY, USA, 2012.

55. Jones, M.; Starkey, F.; Orme, J. Framing youth: Reviewing locally commissioned research on young people, drug use and drug education. In Researching Youth; Bennett, A., Cieslik, M., Miles, S., Eds.; Springer: Hampshire, UK, 2003.

56. Coles, B. Joined-up Youth Research, Policy and Practice: A New Agenda for Change? Youth Work Press: Leicester, UK, 2000.

57. Best, A.L. Representing Youth: Methodological Issues in Critical Youth Studies; NYU Press: New, York, NY, USA, 2007.

58. Whiteley, P. Does citizenship education work? Evidence from a Decade of Citizenship Education in Secondary Schools in England. Parliam. Aff. 2012, 67, 513-535. [CrossRef]

59. IDEA. Voter Turnout Database; IDEA: Rapperswil-Jona, Switzerland, 2017.

60. Norris, P. Digital Divide: Civic Engagement, Information Poverty, and the Internet Worldwide; Cambridge University Press: Cambridge, UK, 2001.

61. Silva, B.C.; Littvay, L. Presenting a Cross-Nationally Validated Populist Attitudes Scale; ECPR: Colchester, UK, 2016.

62. European Commission. European Youth: Participation in Democratic Life; European Commission: Brussels, Belgium, 2013.

63. Sloam, J. Diversity and voice: The political participation of young people in the European Union. Br. J. Politics Int. Relat. 2016, 18, 521-537. [CrossRef]

64. Fieldhouse, E.; Tranmer, M.; Russell, A. Something about young people or something about elections? Electoral participation of young people in Europe: Evidence from a multilevel analysis of the European Social Survey. Eur. J. Political Res. 2007, 46, 797-822. [CrossRef]

65. Kestilä-Kekkonen, E. Anti-party sentiment among young adults: Evidence from fourteen West European countries. Young 2009, 17, 145-165. [CrossRef]

66. Braun, V.; Clarke, V. Using thematic analysis in psychology. Qual. Res. Psychol. 2006, 3, 77-101. [CrossRef]

67. Carlsen, B.; Glenton, C. What about N? A methodological study of sample-size reporting in focus group studies. BMC Med. Res. Methodol. 2011, 11. [CrossRef] [PubMed]

68. Babbie, E. The basics of social research. In Social Work Education; Cengage Learning: Belmont, CA, USA, 2014. 
69. Thomas, F.E.; McGarty, C.; Louis, W. Social interaction and psychological pathways to political engagement and extremism. Eur. J. Soc. Psychol. 2014, 44, 15-22. [CrossRef]

70. Morgan, D.L. Focus Groups as Qualitative Research; SAGE Publications: Thousand Oaks, CA, USA, 1996.

71. Biedermann, N. The use of Facebook for virtual asynchronous focus groups in qualitative research. Contemp. Nurse 2017, 19, 1-9. [CrossRef] [PubMed]

72. Lijadi, A.A.; van Schalkwyk, G.J. Online facebook focus group research of hard-to-reach participants. Int. J. Qual. Methods 2015, 14. [CrossRef]

73. Summanen, I.; Uski, S. Conducting Online Focus Groups in Different Cultures. In "In Search of...": New Methodological Approaches to Youth Research; Allaste, A.-A., Tiidenberg, K., Eds.; Cambridge Scholars Publishing: Newcastle, UK, 2015.

74. Backstrom, L. Anatomy of Facebook. 2011. Available online: https://www.facebook.com/notes/facebookdata-science/anatomy-of-facebook/10150388519243859/ (accessed on 7 March 2018).

75. Thrul, J.; Belohlavek, A.; Hambrick, D.A.; Kaur, M.; Ramo, D.E. Conducting online focus groups on Facebook to inform health behavior change interventions: Two case studies and lessons learned. Int. Interv. 2017, 9, 106-111. [CrossRef] [PubMed]

76. Brüggen, E.; Willems, P. A critical comparison of offline focus groups, online focus groups and e-Delphi. Int. J. Mark. Res. 2009, 51, 363-381.

77. Krueger, R.A.; Casey, M.A. Focus Groups: A Practical Guide for Applied Research; Sage Publications: Thousand Oaks, CA, USA, 2014.

78. Corbin, J.; Strauss, A. Basics of Qualitative Research: Techniques and Procedures for Developing Grounded Theory, 4th ed.; SAGE: London, UK, 2014.

79. Denzin, N.K. The Research Act: A Theoretical Introduction to Sociological Methods; Transaction Publishers: Piscataway, NJ, USA, 1973.

80. Howard, P.N.; Savage, S.; Saviaga, C.F.; Toxtli, C.; Monroy-Hemández, A. Social media, civic engagement, and the slacktivism hypothesis: Lessons from Mexico's “El Bronco". J. Int. Aff. 2016, 70, 55-73.

81. Cabrera, L.N.; Matias, C.E.; Montoya, R. Activism or Slacktivism? The potential and pitfalls of social media in contemporary student activism. J. Divers. High. Educ. 2017. [CrossRef]

82. Lister, R. Why citizenship: Where, when and how children? Theor. Inq. Law 2007, 8, 693-718. [CrossRef]

83. Henn, M.; Oldfield, B.; Hart, J. Postmaterialism and young people's political participation in a time of austerity. Br. J. Sociol. 2017. [CrossRef] [PubMed] 